\title{
PROJECT-BASED LEARNING INTEGRATED TO STEM (STEM-PJBL) TO ENHANCE ARABIC LEARNING HOTS-BASED
}

\section{Uhame Binti Harun ${ }^{1}$}

\author{
Postgraduate of Maulana Malik Ibrahim State Islamic University of Malang, East Java, \\ Indonesia ${ }^{1}$ \\ E-mail: uhamebintiharun96@gmail.com ${ }^{1}$
}

DOI: $\underline{10.14421 / \text { al-bidayah.v12i1.230 }}$

\begin{abstract}
HOTS are the skills needed at this time. STEM-PjBL model is one learning model that can be applied to improve students' higher-order thinking skills. STEM-PjBL is learning that integrates four fields, namely science, technology, engineering, and mathematics, which are project-based learning. Therefore, this learning model encourages students to be active, creative, and innovative in learning, which is in line with the educational goals in Learning Arabic as a foreign language. The research method in this article descriptively is library research. Data obtained from the results of literature studies in the form of books and articles relating to STEM-PjBL using the technique of documentation or searching of library sources for data collection. Data analysis techniques using data triangulation. This study shows that the STEMPjBL learning model is a learning model that can improve students' higher-order thinking skills (HOTS). Also, learning Arabic can use the STEM-PjBL learning model.
\end{abstract}

Keywords: arabic learning; HOTS; PjBL; STEM; STEM-PjBL

\section{INTRODUCTION}

Nowadays, the term Higher-Order Thinking Skills or better known as HOTS is developed, which is high-level thinking skills. HOTS, as the most necessary skill in the 21st century, is part of the cognitive realm that exists in Bloom's Taxonomy, which aims to hone students' thinking or mental skills around knowledge. David Karthwohl later revised Benjamin S. Bloom's concept in his book Taxonomy of Educational Objectives, et al. into six levels, namely: considering, comprehending, applying, analyzing, evaluating, and inventing. ${ }^{1}$ Considering, understanding and applying included in the lowlevel thinking skills (LOTS), whereas analyzing, evaluating, and creating categorized as higher-order thinking skills (HOTS).

In the era of technology and information, if the traditional way of teaching teachers is maintained, then education that aims for students to have high-level thinking skills will not be achieved. Also, we see the development of the world today, expectation a career

${ }^{1}$ Lorin W. Anderson et al., Kerangka Landasan Untuk Pembelajaran, Pengajaran, Dan Asesmen: Revisi Taksonomi Pendidikan Bloom, Translated by: Agung Prihantoro (Yogyakarta: Pustaka Pelajar, 2015), 100-102. 
in technology, and the ability to master the relevant competency in coming decades to increase compared to other fields' jobs. ${ }^{2}$ Therefore, updates and new ideas in the field of education to improve HR (Human Resources) in this era become a necessity. One of them is applying to learn to use the STEM approach.

STEM (Science, Technology, Engineering, and Mathematics) permeates every aspect of the world today. The innovations that emerge from this field can sustain the significant changes that occur. STEM is a learning approach that brings together four areas are science, technology, engineering, and mathematics into one unit. In the world of education, the goals of STEM are following the needs of the 21 st century $^{3}$, which supports learning to have support with technology, and students have scientific literacy. They can develop their competencies in developing products, processes, and systems in life and support problems in the field of science related to daily life using STEM-related. Learning using the STEM approach can improve student creativity, problem-solving skills, and self-motivation to think critically.

The implementation of the STEM approach can apply the Project Based Learning $(\mathrm{PjBL})$. This PjBL learning model focus on contextual learning with a variety of complex activities such as students are free to explore planning their learning activities, implementing projects collaboratively, and produce a product. ${ }^{4}$ Some of the advantages of learning with the STEM approach are that it makes students able to better at solving problems, innovative, be autonomous, logical, critical, and technological literacy. ${ }^{5}$

Experts in the world today have developed various types of technology used as educational facilities, including the use of computer software such as learning media,

2 Till Alexander Leopold, Vesselina Ratcheva, and Saadia Zahidi, The Future of Jobs: Employment, Skills and Workforce Strategy for the Fourth Industrial Revolution (Geneva, Switzerland: World Economic Forum, 2016).

${ }^{3}$ R.W Bybee, The Case for STEM Education: Challenges and Opportunity (Arlington, VI: National Science Teachers Association (NSTA) Press, 2013).

4 Muh Rais, "Project Based Learning: Inovasi Pembelajaran Yang Berorientasi Soft Skills" (Proseding Seminar Nasional Pendidikan Teknologi dan Kejuruan Fakultas Teknik Universitas Negeri Surabaya, Surabaya: Universitas Negeri Surabaya, 2010), https://scholar.google.com/citations?view_op=view_citation\&hl=en\&user=hH8FlycAAAAJ\&citation_for _view=hH8FlycAAAAJ:u5HHmVD_uO8C.

${ }^{5}$ Micah Stohlmann, Tamara Moore, and Gillian Roehrig, "Considerations for Teaching Integrated STEM Education," Journal of Pre-College Engineering Education Research (J-PEER) 2, no. 1 (April 12, 2012), https://doi.org/10.5703/1288284314653. 
educational games, sensor techniques ${ }^{6}$, online learning, and virtual laboratories. ${ }^{7}$ The results of previous studies on STEM-based learning in other subjects made researchers interested in designing STEM-based Arabic learning. Because the expected goals do not match the results on the field; therefore, Arabic Learning needs innovation, students can learn actively and have high-level skills, and can produce Arabic learning products. In this journal, we will discuss STEM approaches, PjBL learning models, and STEM-PjBL in Arabic learning.

\section{RESEARCH METHODS}

\section{Types and Nature of Research}

The type of research used is library research, as one type of research in terms of the place/location of research. ${ }^{8}$ This study obtained data from the results of literature studies in the form of books, literature, notes, and reports that have relevant problems, as well as articles relating to objects using documentation techniques or searching library resources for data collection. ${ }^{9}$ Library research is research whose studies are carried out by tracing and examining literature or written sources relating to the subject (focused on library materials). ${ }^{10}$

The nature of this research is descriptive method. A descriptive study is a research that seeks to tell the solution of existing problems based on data, so he presents the data, analyzes the data, and interprets it. ${ }^{11}$ The descriptive approach aims to describe precisely the characteristics of an individual, the situation or symptoms of a particular group. ${ }^{12}$

6 Niwat Srisawasdi, "Student Teachers' Perceptions of Computerized Laboratory Practice For Science Teaching: A Comparative Analysis," Procedia - Social and Behavioral Sciences, 4th World Conference On Educational Sciences (WCES-2012) 02-05 February 2012 Barcelona, Spain, 46 (January 1, 2012): 4031-38, https://doi.org/10.1016/j.sbspro.2012.06.192.

7 L. Johnson et al., "2013 Technology Outlook for STEM+ Education" (The New Media Consortium, 2013), https://www.learntechlib.org/p/182073/.

${ }^{8}$ Sedarmayanti and S. Hidayat, Metodologi Penelitian (Bandung: Mandar Maju, 2002), 32.

${ }^{9}$ Nazir, Metode Penelitian, 10th ed. (Bogor: Ghalia Indonesia, 2014).

${ }^{10}$ Nazir.

${ }^{11}$ Cholid Narbuko and Abu Achmadi, Metodologi Penelitian (Jakarta: Bumi Aksara, 2007), 43.

12 Z. Asikin Amiruddin, Pengantar Metode Penelitian Hukum (Jakarta: Rajagrafindo Persada Press, 2006), 135. 


\section{Data Sources}

In a study, the researcher needs a data source. ${ }^{13}$ The source of the data in this research is information obtained through a literature review in the form of books and research results related to STEM, PjBL and STEM-PjBL

3) Data collection techniques

In research, collecting data is an important job. Because the data collected will affect the study. ${ }^{14}$ As library research, the data collection technique carried out by researchers is by tracing the sources of library data or books with documentation techniques. Data obtained from documentation provides descriptive information when analyzed..$^{15}$

\section{Data Analysis Technique}

So that researcher can conclude data collected, it requires data analysis techniques as a method used to analyze, study, and process-specific data. Used is a qualitative data analysis technique because the data obtained are qualitative data that is not in the form of numbers, so that it requires careful thinking in solving research problems.

\section{RESULT AND DISCUSSION}

\section{Science, Technology, Engineering, and Mathematics (STEM)}

STEM is a learning approach that integrates four fields, namely Science, Technology, Engineering, and Mathematics. More complete in other references, STEM covers five areas, namely: computers, mathematics and science, architects and technicians, engineers and technicians, physics and life sciences. ${ }^{16}$ STEM is a learning approach with a working system that depends on the relationship of knowledge from each field and also across STEM disciplines. So, learning using the STEM approach is learning that involves students, so students can develop understanding, think critically, and solve problems. Capacity built above through experience in learning. ${ }^{17}$ Based on the learning

${ }^{13}$ Suharsimi Arikunto, Prosedur Penelitian Suatu Pendektan Praktik (The 6th Revission Edition) (Jakarta: Rineka Cipta, 2006), 129.

${ }^{14}$ Arikunto, Prosedur Penelitian Suatu Pendektan Praktik (The 6th Revission Edition).

15 Arikunto, 129.

16 Anthony P. Carnevale, Nicome Smith, and Michelle Melton, STEM (Science, Technology, Engineering and Mathematic) (Washington DC: George Town University, 2011).

17 Ministry for Education and Skills, STEM Education Policy Statement 2017-2026 (Ireland: Ministry for Eduucation and Skills, 2017). 
model using this STEM approach that makes students think critically, analyze the material being studied and can improve students' high-level thinking skills (HOTS).

The goal of STEM is to develop students who are STEM literate in the context of primary and middle education, who have: first, cognitive, attitudes, and skills to identify problems in life situations, to inform about natural phenomena, draft, and writing conclusions based on a proof about issues related to STEM; second, understanding the characteristics of STEM as the form of cognitive, inquiry, and human-initiated design; third, the awareness that the material, intellectual and cultural environment; fourth, willingness to engage in the study of issues related to STEM (example: energy efficiency, environmental quality, limited natural resources) as a constructive, caring, and reflective citizen by using scientific, technological, engineering, and mathematical ideas. ${ }^{18}$

So, STEM is an approach in learning that integrates four fields, namely science, technology, engineering, and mathematics. Expecting students to be more creative in developing their knowledge, thinking critically, and finally producing a technology-based learning product. STEM is useful in learning to improve students' higher-order thinking skills.

\section{Project-Based Learning (PjBL)}

Project-Based Learning (PjBL) is a model that brings students to a high level of creativity with a time that is by one concept of discussion, using media and models that can facilitate students and teachers in learning. Students can connect what they learn and how they can utilized knowledge by using this PjBL model. Learning using this model focuses more on life problems that are meaningful to students. The teacher's role as a facilitator is to show issues, asking questions, and giving facilities to students in designing a project that they do so that it can increase the creativity of students in developing a plan. ${ }^{19} \mathrm{PjBL}$ model is the application of learning following the 21 st-century challenge, that more emphasis on student activity in learning. PjBL model is a learning model that tries to link technology with the problems of everyday life that are familiar with students or with school projects. Learning using this model becomes more effective because it

\footnotetext{
${ }^{18}$ Bybee, The Case for STEM Education: Challenges and Opportunity.

19 Maria Anita Titu, "Penerapan Model Pembelajaran Project Based Learning (PjBL) Untuk Meningkatkan Kreativitas Siswa Pada Materi Konsep Masalah Ekonomi," Prosiding Seminar Nasional Pendidikan Ekonomi FE UNY "Profesionalisme Pendidik Dalam Dinamika Kurikulum Pendidikan Di Indonesia Pada Era MEA, ” June 26, 2015, https://eprints.uny.ac.id/21708/.
} 
focuses on creative thinking, being able to solve problems, and being able to interact with peers to create and use knowledge. Implementation for this learning can apply active learning, scientific dialogue, and others. ${ }^{20}$

PjBL model as process-centered learning, relatively timed, focused on problems, meaningful learning units by integrating concepts from several components both from knowledge, scientific disciplines, or the field. In this learning model, learning activities take place collaboratively in different groups. This learning has the potential to train students' activities and motivation. ${ }^{21} \mathrm{PjBL}$ model help students to be able to design processes, determine an outcome. This model train students to be responsible for managing information carried out on a project. Besides, students can produce a product and then present their product. Students will understand the concepts of the learning material by applying the PjBL model. PjBL model also fosters student creativity, which is closely related to higher-order thinking skills (HOTS).

The steps of learning using the PjBL model, according to The George Lucas Educational Foundation, ${ }^{22}$ explains as follows: the first is the question step. Learning begins with an important question. Take the essential topics from real life and make them relevant to the learning material. The second step is planning. Plan the project to answer essential questions at the beginning of learning. Involve students in questions, design, and create projects. Teachers and students exchange ideas in search of answers to questions. The third step is setting the schedule. The teacher and students arrange the activity schedule. Then, they determine the period. The fourth step is to oversee the project. The teacher supervises students in implementing the project. The aim of supervision is to avoid mistakes in the project work process. The fifth step is an assessment of the product. Then, the evaluation is the sixth step. The teacher is gathering each individual into a group. Then discuss the projects they have been working. Discuss and criticize what they have done. Then share his knowledge for the next new project.

${ }^{20}$ Fathullah Wajdi, "Implementasi Project Based Learning (Pbl) Dan Penilaian Autentik Dalam Pembelajaran Drama Indonesia,” Jurnal Pendidikan Bahasa Dan Sastra 17, no. 1 (June 8, 2017): 86-101, https://doi.org/10.17509/bs_jpbsp.v17i1.6960.

${ }^{21}$ Yulita Dyah Kristanti, Subiki Subiki, and Rif' ati Dina Handayani, "Model Pembelajaran Berbasis Proyek (Project Based Learning Model) Pada Pembelajaran Fisika Disma," Jurnal Pembelajaran Fisika 5, no. 2 (January 28, 2017): 122-28,http://jurnal.unej.ac.id/index.php/JPF/article/download/3958/3086.

${ }^{22}$ Wajdi, "Implementasi Project Based Learning (Pbl) Dan Penilaian Autentik Dalam Pembelajaran Drama Indonesia." 


\section{Arabic Learning}

Arabic, as the second language studied, is one of the Middle Semitic languages and is related to Hebrew and Neo-Arami languages. More than 280 million people have used this language as the first language in parts of the Middle East and North Africa. Arabic has given a lot of vocabulary to other words of the Islamic world, just like Latin to most European languages. ${ }^{23}$ Arabic helps to understand the verses of the Qur'an, as well as a communication tool in conveying information. Besides, Arabic is a tool for spilling the heart. As a foreign language that has many functions, learn Arabic is essential.

Arabic, as a foreign language, a lot of people have studied in a relatively long time, should have a positive influence on students. But the concrete evidence in the field is that students are still not proficient in listening to Arabic, are not yet proficient in speaking Arabic, have difficulty understanding Arabic texts, and writing Arabic rules. Arabic is a discipline that consists of four skills that must be possessed, namely listening, speaking, reading, and writing skills. To get maximum results, the students must learn these skills sequentially. ${ }^{24}$

Arabic teaching has a function to activate Arabic as a communication tool and to help understand the holy Qoran verse to students or learners, both in the sphere of language, education, social, religious, and government. Teaching for learning can be interpreted as a process, way, actions make student learn. ${ }^{25}$ Seeing these facts, indeed, various problems or obstacles in education can make the process of achieving the goals is more complicated. These problems, such as the method is monotonous, lack of teacher innovation in packaging Arabic learning so that it becomes fun and exciting, the contents of books that are not following the reality of students, limited media, and many other problems.

${ }^{23}$ Rahmat Iswanto, "Pembelajaran Bahasa Arab dengan Pemanfaatan Teknologi," Arabiyatuna: Jurnal Bahasa Arab 1, no. 2 (December 29, 2017): 139-52, https://doi.org/10.29240/jba.v1i2.286.

24 Mohammad Thoha, "Pembelajaran Bahasa Arab Dengan Pendekatan Manajemen Berbasis Sekolah," OKARA: Jurnal Bahasa Dan Sastra 6, no. 1 (May 5, 2012), https://doi.org/10.19105/ojbs.v6i1.420.

25 The Drafting Team, "Definisi: Pembelajaran, Arti Kata: Pembelajaran," 2010, https://www.artikata.com/arti-357349-pembelajaran.html. 


\section{Science, Technology, Engineering, and Mathematics (STEM) - Project Based Learning (PjBL) in Arabic Learning}

The PjBL model is one of the recommended models for teaching in the 2013th curriculum, the newest curriculum in Indonesia. This model is one way to improve student abilities to higher-order thinking skills (HOTS). STEM is one of the approaches to learning. PjBL and STEM-PjBL have similarities. The similarities are: first, both of them equally demanding students to be able to determine their learning activities. Second, both of them bring up creative ideas. Third, both of them make students can produce and present a learning product in front of the class. And third, both of them focus on the design process. A design process is a systematic approach to developing solutions to problems with well-defined outcomes. ${ }^{26}$

The STEM-PjBL learning process in guiding students consists of five specific steps. ${ }^{27}$ These steps for Arabic learning are: the first stage is a reflection. The purpose is to get students involved in the context of the problem and inspire them to start investigating the issue immediately. This phase aims to link prior-knowledge dan learning material. The teacher gives issues related to Arabic learning material that will be discussed or projected by students.

The second stage is research. Students research what the teacher has ordered. Students choose Arabic reading or gather the information that is relevant to the problem. This process requires more students to find out for themselves, and more students learn by themselves. During the research process, the teacher acts as a guide. The teacher guides the discussion to determine whether students have developed a conceptual understanding or theory that has been learned and is relevant based on the project they are doing.

The third stage is the discovery. At this stage, it generally involves research processes and student's prior knowledge. Students begin to learn independently and determine what is unknown. The STEM-PjBL model divides students into small groups to present solutions to problems, and collaborates among friends in one group. Other models use these steps in developing students' ability to design or design projects to be developed that are relevant to the given problem. The fourth stage is application. At this

\footnotetext{
${ }^{26}$ Robert M Capraro, Mary Margaret Capraro, and James R Morgan, STEM Project-Based Learning: An Integrated Science, Technology, Engineering, And Mathematics (STEM) Approach (Springer Science \& Business Media, 2013).

27 Diana Laboy-Rush, "Integrated STEM Education Through Project-Based Learning," 2010, http://learning.com/stem/whitepaper/integrated-STEM-throughProject-based-Learning.
} 
stage a trial is carried out on projects that have been designed and designed to solve these problems. In some cases, students test products made with predetermined conditions. The results obtained are used to improve the previous steps.

The fifth stage is communication. The final step in each of these projects is to make products by communicating between friends and between classes. Presentation is the most crucial thing in the learning process using this STEM-PjBL. This performance is useful for training students' communication and collaboration skills, as well as training students to accept criticism of suggestions and provide suggestions so that the product becomes better.

Research on STEM-PjBL has been conducted before in science learning. Research conducted by Afriana, et al., ${ }^{28}$ the study shows that STEM-PjBL can increase scientific literacy and exciting teaching and motivate students, help understand teaching material, shape creative attitudes and improve students' ability to operate information technology. The application of STEM-PjBL can improve students' creative learning abilities, having passion, and desire to learn. STEM-PjBL can improve students' creative thinking abilities. ${ }^{29}$ After a simple analysis of the steps and learning objectives using the STEMPjBL model, learning using the STEM-PjBL model can upgrade higher-order thinking skills (HOTS). Learning that is carried out with the STEM-PjBL model that has been applied, is considered useful because this model invites students to do meaningful learning in understanding a concept and exploring through project making so that students will be actively involved in the teaching. Of course, learning by using this model can encourage students to think critically, creatively, analytically, and upgrade students to have higher-order thinking skills..

\section{CONCLUSION}

Learning using the science, technology, engineering, and mathematics-project based learning approach (STEM-PjBL) can improve student's higher-order thinking skills (HOTS). Because, STEM-PjBL model requires students to be active, creative and

28 Farah Robi'atul Jauhariyyah, Hadi Suwono, and Ibrohim Ibrohim, "Science, Technology, Engineering and Mathematics Project Based Learning (STEM-PjBL) pada Pembelajaran Sains," Seminar Nasional Pendidikan IPA $2017 \quad 2, \quad$ no. $0 \quad$ (February $19, \quad 2018$ ), http://pasca.um.ac.id/conferences/index.php/ipa2017/article/view/1099.

29 Ani Ismayani, "Pengaruh Penerapan STEM Project-Based Learning Terhadap Kreativitas Matematis Siswa SMK," Indonesian Digital Journal of Mathematics and Education 3, no. 4 (2016): 26472, http://idealmathedu.p4tkmatematika.org/wp-content/uploads/IME-V3.4-07.Ani_Ismayani.pdf. 
innovative. So that students become aware of the material being studied, have high motivation, have the ability to be creative, increase the effectiveness of meaningful learning, and support future careers.

Departing from this study, subsequent studies of the STEM-PjBL model can follow up on the results of this study. Such as research on the application of STEM-PjBL models in various levels and contexts of other subject matter, research on the meta-analysis of research on the effectiveness of STEM-PjBL, and research on the effect of STEM-PjBL on learning outcomes, learning motivation, or skills creative thinking, innovative, critical thinking, and problem-solving.

\section{REFERENCES}

Amiruddin, Z. Asikin. Pengantar Metode Penelitian Hukum. Jakarta: Rajagrafindo Persada Press, 2006.

Anderson, Lorin W., David R. Krathwohl, Peter W. Airasian, Kathleen A. Cruikshank, Richard E. Mayer, Paul R. Pintrich, James Raths, and Merlin C. Wittrock. Kerangka Landasan Untuk Pembelajaran, Pengajaran, Dan Asesmen: Revisi Taksonomi Pendidikan Bloom, Translated by: Agung Prihantoro. Yogyakarta: Pustaka Pelajar, 2015.

Anita Titu, Maria. "Penerapan Model Pembelajaran Project Based Learning (PjBL) Untuk Meningkatkan Kreativitas Siswa Pada Materi Konsep Masalah Ekonomi." Prosiding Seminar Nasional Pendidikan Ekonomi FE UNY "Profesionalisme Pendidik Dalam Dinamika Kurikulum Pendidikan Di Indonesia Pada Era MEA, ”June 26, 2015. https://eprints.uny.ac.id/21708/.

Arikunto, Suharsimi. Prosedur Penelitian Suatu Pendektan Praktik (The 6th Revission Edition). Jakarta: Rineka Cipta, 2006.

Bybee, R.W. The Case for STEM Education: Challenges and Opportunity. Arlington, VI: National Science Teachers Association (NSTA) Press, 2013.

Capraro, Robert M, Mary Margaret Capraro, and James R Morgan. STEM Project-Based Learning: An Integrated Science, Technology, Engineering, And Mathematics (STEM) Approach. Springer Science \& Business Media, 2013.

Carnevale, Anthony P., Nicome Smith, and Michelle Melton. STEM (Science, Technology, Engineering and Mathematic). Washington DC: George Town University, 2011.

Ismayani, Ani. "Pengaruh Penerapan STEM Project-Based Learning Terhadap Kreativitas Matematis Siswa SMK." Indonesian Digital Journal of Mathematics and Education 3, no. 4 (2016): 264-72, http://idealmathedu.p4tkmatematika.org/wp-content/uploads/IME-V3.407.Ani_Ismayani.pdf. 
Iswanto, Rahmat. "Pembelajaran Bahasa Arab dengan Pemanfaatan Teknologi." Arabiyatuna: Jurnal Bahasa Arab 1, no. 2 (December 29, 2017): 139-52. https://doi.org/10.29240/jba.v1i2.286.

Jauhariyyah, Farah Robi'atul, Hadi Suwono, and Ibrohim Ibrohim. "Science, Technology, Engineering and Mathematics Project Based Learning (STEMPjBL) pada Pembelajaran Sains.” Seminar Nasional Pendidikan IPA 2017 2, no. $0 \quad$ (February 19, 2018). http://pasca.um.ac.id/conferences/index.php/ipa2017/article/view/1099.

Johnson, L., S. Adams Becker, V. Estrada, and S. Martín. "2013 Technology Outlook for STEM+ Education." The New Media Consortium, 2013. https://www.learntechlib.org/p/182073/.

Kristanti, Yulita Dyah, Subiki Subiki, and Rif'ati Dina Handayani. "Model Pembelajaran Berbasis Proyek (Project Based Learning Model) Pada Pembelajaran Fisika Disma." Jurnal Pembelajaran Fisika 5, no. 2 (January 28, 2017): 122-28, http://jurnal.unej.ac.id/index.php/JPF/article/download/3958/3086.

Laboy-Rush, Diana. "Integrated STEM Education Through Project-Based Learning," 2010. http://learning.com/stem/whitepaper/integrated-STEM-throughProjectbased-Learning.

Leopold, Till Alexander, Vesselina Ratcheva, and Saadia Zahidi. The Future of Jobs: Employment, Skills and Workforce Strategy for the Fourth Industrial Revolution. Geneva, Switzerland: World Economic Forum, 2016.

Ministry for Education and Skills. STEM Education Policy Statement 2017-2026. Ireland: Ministry for Eduucation and Skills, 2017.

Narbuko, Cholid, and Abu Achmadi. Metodologi Penelitian. Jakarta: Bumi Aksara, 2007.

Nazir. Metode Penelitian. 10th ed. Bogor: Ghalia Indonesia, 2014.

Rais, Muh. "Project Based Learning: Inovasi Pembelajaran Yang Berorientasi Soft Skills." Surabaya: Universitas Negeri Surabaya, 2010. https://scholar.google.com/citations?view_op=view_citation\&hl=en\&user=hH8 FlycAAAAJ\&citation_for_view=hH8FlycAAAAJ:u5HHmVD_uO8C.

Sedarmayanti, and S. Hidayat. Metodologi Penelitian. Bandung: Mandar Maju, 2002.

Stohlmann, Micah, Tamara Moore, and Gillian Roehrig. "Considerations for Teaching Integrated STEM Education." Journal of Pre-College Engineering Education Research (J-PEER) 2, no. 1 (April 12, 2012). https://doi.org/10.5703/1288284314653.

The Drafting Team. "Definisi: Pembelajaran, Arti Kata: Pembelajaran," 2010. https://www.artikata.com/arti-357349-pembelajaran.html.

Thoha, Mohammad. "Pembelajaran Bahasa Arab Dengan Pendekatan Manajemen Berbasis Sekolah." OKARA: Jurnal Bahasa Dan Sastra 6, no. 1 (May 5, 2012). https://doi.org/10.19105/ojbs.v6i1.420.

Wajdi, Fathullah. "Implementasi Project Based Learning (Pbl) Dan Penilaian Autentik Dalam Pembelajaran Drama Indonesia." Jurnal Pendidikan Bahasa Dan Sastra 17, no. 1 (June 8, 2017): 86-101. https://doi.org/10.17509/bs_jpbsp.v17i1.6960. 
STEM-PjBL to Enhance Arabic Learning...

150 | Al-Bidayah, Volume 12, Number 1, June 2020 